\title{
First Principles Investigation of Zinc-anode Dissolution in Zinc-air Batteries
}

Siahrostami, Samira; Tripkovic, Vladimir; Lundgård, Keld Troen; Jensen, Kristian E.; Hansen, Heine A.; Hummelshøj, Jens Strabo; Mýrdal, Jón Steinar Garðarsson; Vegge, Tejs; Nørskov, Jens Kehlet;

Rossmeisl, Jan

Published in:

Physical Chemistry Chemical Physics

Link to article, DOI:

10.1039/C3CP50349F

Publication date:

2013

Document Version

Publisher's PDF, also known as Version of record

Link back to DTU Orbit

Citation (APA):

Siahrostami, S., Tripkovic, V., Lundgård, K. T., Jensen, K. E., Hansen, H. A., Hummelshøj, J. S., Mýrdal, J. S. G., Vegge, T., Nørskov, J. K., \& Rossmeisl, J. (2013). First Principles Investigation of Zinc-anode Dissolution in Zinc-air Batteries. Physical Chemistry Chemical Physics, 15, 6416-6421. https://doi.org/10.1039/C3CP50349F

\section{General rights}

Copyright and moral rights for the publications made accessible in the public portal are retained by the authors and/or other copyright owners and it is a condition of accessing publications that users recognise and abide by the legal requirements associated with these rights.

- Users may download and print one copy of any publication from the public portal for the purpose of private study or research.

- You may not further distribute the material or use it for any profit-making activity or commercial gain

- You may freely distribute the URL identifying the publication in the public portal 
Cite this: Phys. Chem. Chem. Phys., 2013

\section{First principles investigation of zinc-anode dissolution in zinc-air batteries}

15, 6416

Received 25th January 2013,

Accepted 25th February 2013

DOI: $10.1039 / \mathrm{c} 3 \mathrm{cp} 50349 f$

www.rsc.org/pccp

\author{
Samira Siahrostami, ${ }^{\text {ab }}$ Vladimir Tripković, ${ }^{a}$ Keld T. Lundgaard, ${ }^{a}$ Kristian E. Jensen, ${ }^{a}$ \\ Heine A. Hansen, ${ }^{c}$ Jens S. Hummelshøj, ${ }^{d}$ Jón S. G. Mýrdal, ${ }^{\text {ae }}$ Tejs Vegge, \\ Jens K. Nørskov ${ }^{c d}$ and Jan Rossmeis|*a
}

\section{Introduction}

Although the technology originated in the 19 th century, ${ }^{1}$ metalair batteries were first put into commercial use in the beginning of the 20th century. They became increasingly popular in the seventies when the first button cells appeared in the market. In recent years, increasing global energy demand along with the depletion of the carbon based natural resources have inspired the pursuit for alternative energy supplies. This has brought battery technology under the spotlight and has encouraged the scientific community to revisit and overcome problems that have impeded its large-scale utilization.

Metal-air batteries are similar to Fuel Cells (FCs); the only difference being that the batteries are energy storage devices, while FCs are energy converting devices. In the past, a few potential candidates such as $\mathrm{Li}, \mathrm{Ca}, \mathrm{Mg}, \mathrm{Cd}, \mathrm{Al}, \mathrm{Zn}$ and $\mathrm{Fe}$ have been investigated as possible energy carriers in metal-air

\footnotetext{
${ }^{a}$ Center for Atomic-scale Materials Design (CAMD), Department of Physics,

Technical University of Denmark, DK-2800 Lyngby, Denmark. E-mail: Jan.Rossmeisl@fysik.dtu.dk

${ }^{b}$ Department of Chemistry, College of Science, Shiraz University, Shiraz 71454, Iran

${ }^{c}$ Department of Chemical Engineering, Stanford University, Palo Alto, CA 94305, USA

${ }^{d}$ Center for Interface Science and Catalysis, SLAC National Accelerator Laboratory, 2575 Sand Hill Rd, Menlo Park, CA 94025, USA

${ }^{e}$ Department of Energy Conversion and Storage, Technical University of Denmark, DK-4000 Roskilde, Denmark
}

batteries. The use of earth abundant metals makes this technology much cheaper than the FC technology. In addition, using oxygen from air as the cathode oxidant allows the battery to be filled with more anode material, which significantly increases the energy densities of the systems, albeit power densities remain low. Metal-air cells are characterized by a very flat discharge profile, which points to a minute potential loss over time. ${ }^{1}$

Due to its various advantages, zinc was the first metal implemented in the metal-air batteries. It is abundant, rather inexpensive and stable in aqueous and alkaline electrolytes. In addition, it has environmental benignity, low equilibrium potential and flat discharge voltage., ${ }^{2,3}$ The zinc-air battery is the only commercialized cell in the metal-air family and hitherto only a primary (non-rechargeable) battery. ${ }^{4} \mathrm{Li}$-air cells potentially possess higher energy density than zinc-air, ${ }^{5}$ but remain challenged by limited current densities and sudden death, ${ }^{6}$ and furthermore, the fundamental mechanisms are not yet fully understood. ${ }^{5-7}$ The zincair cells are primarily used as large batteries for applications such as railroad signaling and remote communications. Since the development of thin electrodes, they have been used in small, high capacity primary cells, such as small electronics, medical devices (hearing aids) and other small appliances that demand low currents over a long period of time without the need for recharging.

Primary zinc-air batteries have remained an excellent choice in the metal-air family and are considered very successful commercially. They are cheap, easy to handle and environmentally friendly. Nevertheless, they feature some significant drawbacks, 
limiting the development of this technology, i.e. making secondary, electrically rechargeable batteries, or using Zn-air technologies for vehicle propulsion. ${ }^{5-7}$ Among these, the most important ones are: anode corrosion, carbonate formation from the $\mathrm{CO}_{2}$ in air, which decreases the conductivity of the electrolyte, high sensitivity to temperature and humidity, high self-discharge and zinc dendrite formation, where zinc builds unevenly in the form of branch-like structures that can short circuit the electrodes and eventually destroy the cell. ${ }^{8}$ Besides, a major challenge pertains to making this technology rechargeable with high efficiency. This could be achieved by a bifunctional catalyst capable of performing both the Oxygen Reduction Reaction (ORR) during the discharging cycle and the Oxygen Evolution Reaction (OER) during the charging cycle. ${ }^{9}$ We have previously studied theoretically which are the best catalysts for $\mathrm{ORR}^{10,11}$ and $\mathrm{OER}^{12,13}$ among different classes of materials, but the challenge still persists in combining the two. ${ }^{14,15}$ Another plausible technical solution is to make a three-electrode cell with two cathodes, one for the ORR and other for the OER, but this design significantly increases the size and complexity of the cell. ${ }^{16}$

The cathode reactions have justifiably received much attention in the development of secondary zinc-air ${ }^{17}$ and other metal-air batteries. ${ }^{5}$ Few studies have been devoted to improve the anode to be able to design electrically rechargeable and mechanically refuelable zinc-air cells. ${ }^{18-20}$ As a matter of fact, establishing an understanding of the fundamental reaction mechanisms at the anode and, equally important, the computational methodology to analyze and predict such reactions is an essential aspect in the design of future, electrically rechargeable systems.

The anode of the zinc-air cell is in the form of zinc paste and in excess of hydroxyl species, it oxidizes to the zincate anion $\left[\mathrm{Zn}(\mathrm{OH})_{4}\right]^{2-}$ and dissolves into the electrolyte solution, while two electrons are released and transferred to the cathode where oxygen is reduced. The zinc anode dissolution makes the recharge cycle difficult, because there is no connection between the electrode and the solvated zincate ion. Non-precious $\mathrm{MnO}_{2}$ is used as cathode material, while $\mathrm{KOH}$ is often chosen as an electrolyte, due to its very good ionic conductance. Half reactions taking place at both electrodes are shown below.

Anode reaction:

$$
\begin{gathered}
{\left[\mathrm{Zn}(\mathrm{OH})_{4}\right]^{2-}+2 \mathrm{e}^{-} \rightarrow \mathrm{Zn}+4 \mathrm{OH}^{-} \quad E^{\theta}=-1.199 \mathrm{~V} \text { (ref. 21) }} \\
{\left[\mathrm{Zn}(\mathrm{OH})_{4}\right]^{2-} \rightarrow \mathrm{ZnO}+\mathrm{H}_{2} \mathrm{O}+2 \mathrm{OH}^{-}}
\end{gathered}
$$

Cathode reaction:

$$
1 / 2 \mathrm{O}_{2}+\mathrm{H}_{2} \mathrm{O}+2 \mathrm{e}^{-} \rightarrow 2 \mathrm{OH}^{-} \quad E^{\theta}=0.401 \mathrm{~V}
$$

Adding these two half reactions and their standard potentials together gives the overall reaction and the potential of the system.

Overall:

$$
\mathrm{Zn}+1 / 2 \mathrm{O}_{2} \rightarrow \mathrm{ZnO} \quad E^{\theta}=1.60 \mathrm{~V}
$$

It is important to note here that the definition of standard potential implies that reaction takes place under standard conditions in $1 \mathrm{M}$ solution of each aqueous species. As one of the aqueous species is $\mathrm{OH}^{-}$this automatically implies that the potentials in the above reaction are estimated at $\mathrm{pH} 14$. The maximum work that can be extracted from the system is $1.60 \mathrm{eV}$ per electron, albeit the operating voltage is only $\sim 1.30 \mathrm{~V},{ }^{1}$ due to kinetic losses mostly related to the ORR at the cathode.

In this contribution, we focus on the chemistry of the zincate anion formation in alkaline solution. We establish the free energy diagram (FED) for zinc dissolution at the anode side of the zinc-air battery. This is a continuation of our previous work in which we modeled a $\mathrm{Li}$-air cell in aprotic solvent. ${ }^{22,23}$ We first introduce two different models for zinc dissolution, then we use a simple method to account for a finite bias and finally we show that there is a very small overpotential for this reaction. Although dissolution processes have been previously successfully studied with $\mathrm{DFT}^{24-26}$ this is, to the best of our knowledge, the first attempt to model the electrochemical dissolution of zinc using DFT.

\section{Computational details}

All electronic structure calculations are carried out using the GPAW program package, which is a density functional theory implementation, based on the projector-augmented wave method that uses real-space uniform grids. ${ }^{27}$ The grid spacing is set to $h=0.15 \AA$, as a tradeoff between computational efficiency and accuracy. The standard GGA-RPBE functional is chosen to describe the exchange and correlation part. ${ }^{28}$ Two different slab models are used for comparison, the (0001) surface and a kink surface. The $\mathrm{Zn}(0001)$ surface is modeled by a periodically repeated five layers thick $3 \times 4$ unit cell of which three topmost layers are allowed to relax. The Brillouin zone was sampled with a $(4 \times 4 \times 1)$ Monkhorst-Pack $k$-point grid. For the kink model the $\mathrm{Zn}$ surface is represented by a periodically repeated six-layer slab. The two bottom layers are held fixed while the rest are allowed to relax. The Brillouin zone is sampled by the $(3 \times 4 \times 1)$ Monkhorst-Pack $k$-point grid. ${ }^{29}$ In both models periodic images are separated by $20 \AA$ of vacuum in the direction perpendicular to the surface. All geometric optimizations are carried out using the quasi-Newton minimization scheme and the calculations are considered converged when residual forces on all atoms are less than $0.05 \mathrm{eV} \AA^{-1}$. Fermi smearing is set to $0.1 \mathrm{eV}$, and all the energies are extrapolated to an electronic temperature of $0 \mathrm{~K}$. All the calculations are performed in the ASE. $^{30}$

We start by addressing simple issues regarding lattice constants and the chosen models. The optimized lattice constants of zinc $(a=2.66, c=5.37, a / c=2.02)$ compare well with other theoretical DFT-GGA $(a=2.65, c=5.12, a / c=1.93)^{31}$ and experimental $(a=$ 2.67, $c=4.95, a / c=1.86)^{32}$ values found in the literature. The same agreement holds for the wulfenite structure of $\mathrm{Zn}(\mathrm{OH})_{2}(a=4.96$, $b=5.23, c=8.91$ ), where our data are compared to the only experimental source available $(a=4.92, b=5.16, c=8.49) .{ }^{33}$ The calculated formation energy of bulk $\mathrm{Zn}(\mathrm{OH})_{2}$ is $2.35 \mathrm{eV}$, which is very close to the experimentally determined value of $2.5 \mathrm{eV}$. $^{34}$ Somewhat larger $c$ lattice constant is related to the choice of the exchange-correlation functional. The RPBE functional is known to 
slightly overestimate lattice constants, but in return it gives much better adsorption energies of small molecules on metal surfaces, which we are concerned about in this work. ${ }^{28}$

\section{Results and discussions}

The electrochemical conversion of the zinc surface is efficient as long as the active metal surface is exposed to the electrolyte. It has been speculated experimentally that zinc undergoes sequential dissolution to form the $\left[\mathrm{Zn}(\mathrm{OH})_{4}\right]^{2-}$ ion:

$$
\begin{gathered}
\mathrm{Zn}+\mathrm{OH}^{-} \rightarrow \mathrm{ZnOH}+\mathrm{e}^{-} \\
\mathrm{ZnOH}+\mathrm{OH}^{-}+\mathrm{e}^{-} \rightarrow \mathrm{Zn}(\mathrm{OH})_{2}+2 \mathrm{e}^{-} \\
\mathrm{Zn}(\mathrm{OH})_{2}+\mathrm{OH}^{-} \rightarrow\left[\mathrm{Zn}(\mathrm{OH})_{3}\right]^{-} \\
{\left[\mathrm{Zn}(\mathrm{OH})_{3}\right]^{-}+\mathrm{OH}^{-} \rightarrow\left[\mathrm{Zn}(\mathrm{OH})_{4}\right]^{2-}}
\end{gathered}
$$

where $\mathrm{Zn}(\mathrm{OH})$ and $\mathrm{Zn}(\mathrm{OH})_{2}$ are bulk hydroxides. The equilibrium potential for the formation of the ionic species $\left[\mathrm{Zn}(\mathrm{OH})_{3}\right]^{-}$and $\left[\mathrm{Zn}(\mathrm{OH})_{4}\right]^{2-}$ is $1.15 \mathrm{~V}$ and $1.199 \mathrm{~V}$, respectively, at $\mathrm{pH} 14 .^{34}$

The standard electrode potentials for the reactions taking place inside the $\mathrm{Zn}$-air cell are shown in Fig. 1 as a function of pOH $(14-\mathrm{pH})$. The zinc dissolution to $\mathrm{Zn}(\mathrm{OH})_{2}$ is an electrochemical process as it involves transfer of two electrons; however, further dissolution to the aqueous species is a chemical process, which depends on the $\mathrm{pH} / \mathrm{pOH}$ of the solution. Under very alkaline conditions (low $\mathrm{pOH} /$ high $\mathrm{pH}$ ) the $\left[\mathrm{Zn}(\mathrm{OH})_{3}\right]^{-}$and $\left[\mathrm{Zn}(\mathrm{OH})_{4}\right]^{2-}$ energy levels are almost in equilibrium (violet and black lines). Fig. 1 also gives an explanation of why $\left[\mathrm{Zn}(\mathrm{OH})_{4}\right]^{2-}$ decays spontaneously to $\mathrm{ZnO}$. The reason is that $\mathrm{ZnO}$ is chemically the most stable state in the entire $\mathrm{pOH} / \mathrm{pH}$ range. This is at the same time the main reason why it is hard to do the reverse reaction, i.e. to recharge the battery - one needs to overcome a thermodynamic barrier regardless of $\mathrm{pH}$ and potential. The difference between the blue line (cathode reaction) and the green line (anode reaction) is the equilibrium cell potential (ECP). At higher pOH values the ECP will become

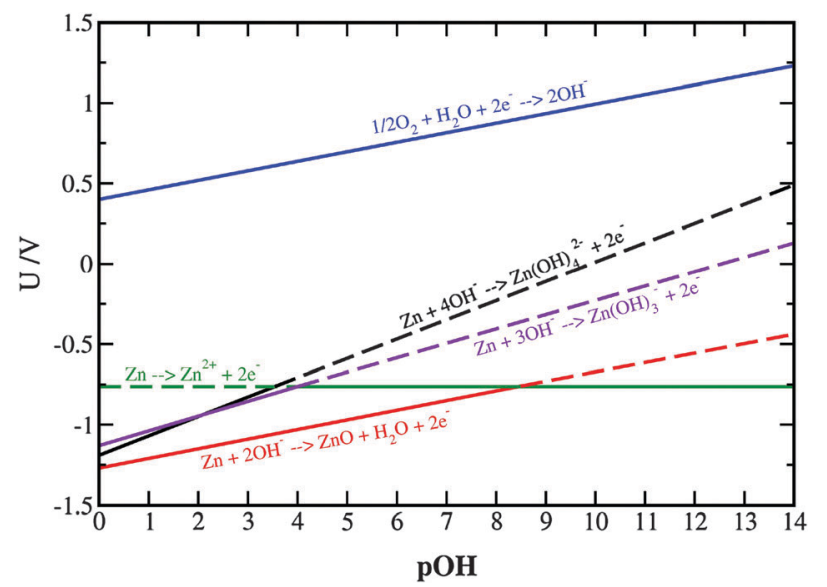

Fig. 1 Standard electrode potentials for the cathode and anode reactions in the zinc-air cell are plotted as a function of $\mathrm{pOH}$. smaller because $\left[\mathrm{Zn}(\mathrm{OH})_{3}\right]^{-}$and $\left[\mathrm{Zn}(\mathrm{OH})_{4}\right]^{2-}$ ion stabilities decrease with increasing acidity (black and violet lines). At pOH 4 , the $\mathrm{Zn}^{2+}$ ion becomes the dominant species in the solution. This will affect the ECP as it will start to increase gradually. At ca. pOH 8.5, the ECP will be even higher than that at pOH $0(c a .1 .60 \mathrm{~V})$. At first glance, from this simple thermodynamic analysis, one would conclude that it is better to run the reaction in an acidic environment; however, as no protons are produced at the anode, while they are quickly spent at the cathode, the electrolyte $\mathrm{pH}$ will swiftly change to $\mathrm{pOH} 4$, where new equilibrium will be established.

The goal of the study is to model bulk dissolution and for that reason the choice of the right model becomes essential. Two qualitatively different models are used to investigate the zinc dissolution. The first model is the bare $\mathrm{Zn}(0001)$ surface (Fig. 2, panel (a)), which is at the same time the most stable $\mathrm{Zn}$ facet. With increasing number of $\mathrm{OH}$ species the $\mathrm{Zn}$ atom starts to displace from the surface. The most stable configurations for the first and second adsorbed $\mathrm{OH}$ groups are shown in Fig. 2 (panels (b) and (c)). The first $\mathrm{OH}$ sits on the hollow site and the second $\mathrm{OH}$ adsorbs on the neighboring hollow site close to the first. An additional $\mathrm{OH}$ group dissolves $\mathrm{Zn}$ atoms and vacancies are formed at the $\mathrm{Zn}(0001)$ surface (panel (d) in Fig. 2).

For the second model we adopted a kink surface with the following two features. Firstly, kink atoms (most under coordinated defect sites) make the strongest bonds to adsorbates and thus they will be the first ones to dissolve. Secondly, when a kink atom is dissolved, it leaves another kink on the surface. As a result, there is no net change in the surface morphology and hence the surface energy remains the same. The difference in energy, before and after dissolution of a kink atom, thus corresponds to the energy of one zinc atom in the bulk. To ascertain this point we have compared the cohesive energy of $\mathrm{Zn}$ with the energy difference of the clean surface before and after dissolution of a single kink atom. A small energy difference of $0.04 \mathrm{eV}$ justifies the choice of this model.

The intermediates formed during a single dissolution cycle are illustrated in Fig. 3. The most stable $\mathrm{OH}$ adsorption site on the selected kink surface is the bridge site next to the kink atom (panel (b)). Subsequent $\mathrm{OH}$ groups are adsorbed on the step, until all the step sites are covered (panels (c) and (d)). In the end, each zinc atom at the step is bonded to two $\mathrm{OH}$ groups (panel d). Additional OH species bind to the kink atom and the kink atom starts to dissolve gradually from the surface (panel (e)). It is evident from panels (b) and (f) that the surface morphology remains unchanged after a dissolution cycle, implying that the zinc surface dissolves literally kink atom by kink atom.

\section{Free energy diagram}

The FED for zinc dissolution is presented in Fig. 4. Before the results are discussed, we briefly outline how the FED is constructed. The last two steps in the FED are fixed to the dissolution potentials of zinc, forming $\left[\mathrm{Zn}(\mathrm{OH})_{3}\right]^{-}$and $\left[\mathrm{Zn}(\mathrm{OH})_{4}\right]^{2-}$ ions. The experimental values are used because it is hard to estimate the free energy levels of solvated ions with DFT. Since $\mathrm{Zn}$ atoms dissolve after two steps in the $\mathrm{Zn}(0001)$ 


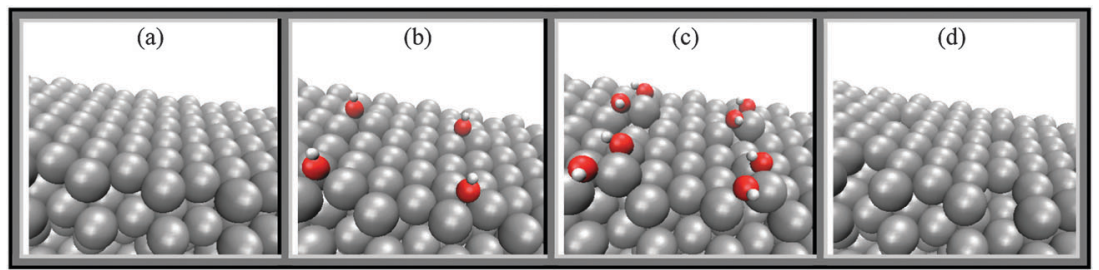

Fig. 2 The bare $\mathrm{Zn}(0001)$ surface is illustrated in panel (a). Panels (b) and (c) are the most stable configurations for the first and second OH adsorbate, respectively. Additional $\mathrm{OH}$ groups dissolve $\mathrm{Zn}$ atoms and vacancies are formed at the $\mathrm{Zn}(0001)$ surface (panel (d)). The surface is repeated twice in both [100] and [010] directions.

surface model (Fig. 2), the free energy of vacancy formation is added on top of the experimental $\left[\mathrm{Zn}(\mathrm{OH})_{3}\right]^{-}$and $\left[\mathrm{Zn}(\mathrm{OH})_{4}\right]^{2-}$ values i.e. the last two steps of red and green lines in Fig. 4.

To obtain the free energy levels of solid phases, $\mathrm{Zn}(\mathrm{OH})$ and $\mathrm{Zn}(\mathrm{OH})_{2}$, a simple method previously developed to model the thermochemistry of electrochemical reactions is applied. ${ }^{10}$ The adsorption energy of $\mathrm{OH}$ is calculated through the reaction energy of $\mathrm{H}_{2} \mathrm{O}+{ }^{*} \rightarrow \mathrm{HO}^{*}+\mathrm{H}^{+}+\mathrm{e}^{-}$. This way the effect of liquid water is implicitly taken into account however, the interaction of water with adsorbed $\mathrm{OH}$ through hydrogen bonding can further stabilize the $\mathrm{OH}$ species. Herein, we have incorporated adsorbed $\mathrm{OH}$ in a hexagonal hydrogen bonded network with water. The existence of the hexagonal water layer on $\mathrm{Pt}(111)$ has been proven experimentally ${ }^{36,37}$ and applied in theoretical calculations. ${ }^{38-40}$ The hexagonal water layer is adjusted to the $\mathrm{Zn}(0001)$ unit cell for the purpose of this work. The stabilization energy due to formation of hydrogen bonds is estimated as the free energy difference between the $\mathrm{OH}$ adsorbed on the $\mathrm{Zn}(0001)$ surface with and without the hydrogen bonded network. The obtained value of $0.57 \mathrm{eV}$ is used as an estimate for the water induced stabilization energy per $\mathrm{OH}$ species both for the $\mathrm{Zn}(0001)$ and kink surfaces. The solvation correction seems reasonable in comparison with a similar correction of $\sim 0.5 \mathrm{eV}$ calculated on the $\mathrm{Pt}(111)$ surface. $^{10,43}$

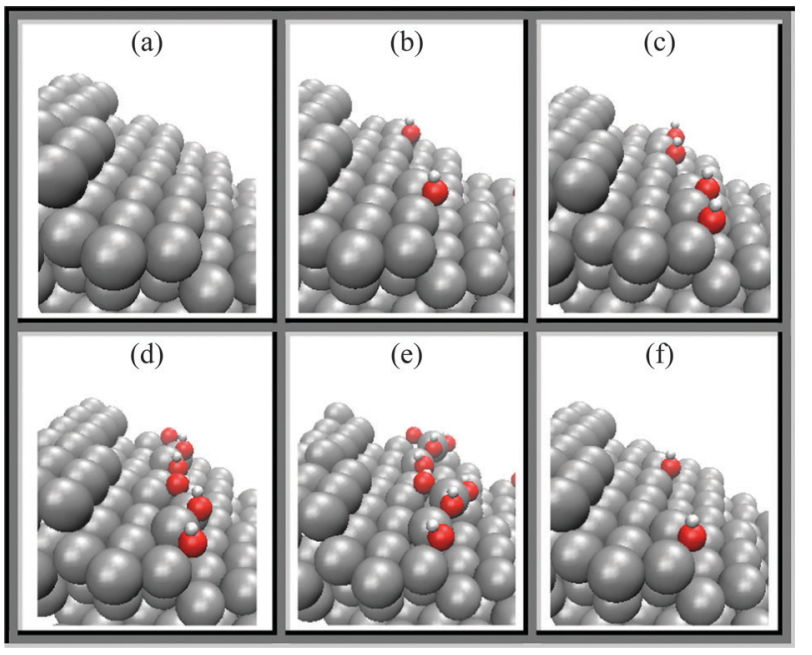

Fig. 3 The kink slab is cartooned in panel (a). Panels (b) to (e) show steps in one dissolution cycle. The surface is repeated twice in both the [100] and [010] directions. In panel (f) the first kink atom is dissolved and the surface is ready for the next cycle.
The bias effect on the free energy levels involving charge transfer is described by the $-n e U$ term, where $U$ is the electrode potential $v s$. SHE and $n$ is the number of transferred electrons. The pH effect is not explicitly included in the DFT calculations and, therefore, has to be added a posteriori. To account for the alkaline environment ( $\mathrm{pH}$ 14) the free energy levels of the $\mathrm{OH}$ species are shifted by $-0.059 \times \mathrm{pH}=-0.83 \mathrm{eV}$. The total of the zero point energy $(\triangle \mathrm{ZPE})$ and entropy change $(-T \Delta S)$ obtained from normal mode analysis and thermodynamic tables ${ }^{35}$ for the reaction $\mathrm{H}_{2} \mathrm{O}+{ }^{*} \rightarrow \mathrm{HO}^{*}+1 / 2 \mathrm{H}_{2}$ is found to be $0.39 \mathrm{eV}$ per $\mathrm{OH}$ species at room temperature. The total free energy correction for the adsorbed $\mathrm{OH}$ species is given by

$$
\Delta G=\Delta E_{\mathrm{w}, \text { water }}+\Delta \mathrm{ZPE}-T \Delta S-0.059 \times \mathrm{pH}-n e U
$$

where $\Delta E_{\mathrm{w}, \text { water }}$ is the free adsorption energy including the water induced stabilization energy.

The FED in Fig. 4 is shown at zero cell potential, and at the smallest potential where all the reaction steps are downhill in free energy. The latter FED is obtained by shifting the free energy levels at $U=0 \mathrm{~V}$ by chemical potential of electrons according to the last term in eqn (9). The difference between the theoretical equilibrium potential is $-1.199 \mathrm{~V}$ and this potential is the thermodynamic overpotential required to run the reaction. Red and green lines are the FED on the $\mathrm{Zn}(0001)$ surface at $U=0 \mathrm{~V}$ and $-0.50 \mathrm{~V}$, respectively. Clearly, the $\mathrm{Zn}(0001)$ surface is a bad model for bulk dissolution since the overpotential is poorly estimated to be $0.70 \mathrm{~V}$, far from the experimentally measured one, i.e. $0.05-0.1 \mathrm{~V} .^{41,42}$ The reason for this huge difference is that after dissolution of a single $\mathrm{Zn}$ atom the surface is left with a vacancy, hence the adsorption energy is higher. Similarly, black and blue lines in Fig. 4 indicate the FED for the kink model at $U=0 \mathrm{~V}$ and minimum overpotential $(U=-1.07 \mathrm{~V})$. The kink model gives much better agreement with experiments and predicts $0.13 \mathrm{~V}$ overpotential for the anode reaction. Furthermore, Fig. 4 shows that the reverse process, important for recharging the battery, will also most likely happen on the kink site. By comparing the green and the blue lines in Fig. 4, it is obvious that there is a much larger thermodynamic barrier for dehydroxylating $\left[\mathrm{Zn}(\mathrm{OH})_{3}\right]^{-}$ to $\mathrm{Zn}(\mathrm{OH})_{2}$ on the $\mathrm{Zn}(0001)$ surface than on kink, and this barrier cannot be overcome by changing the bias. Again, the reason why the kink model yields much better results is related to the aforementioned similarity between the kink and the bulk dissolution. The formation energy of $\mathrm{Zn}(\mathrm{OH})_{2}$ in bulk has also been denoted for comparison (orange). There is a good 


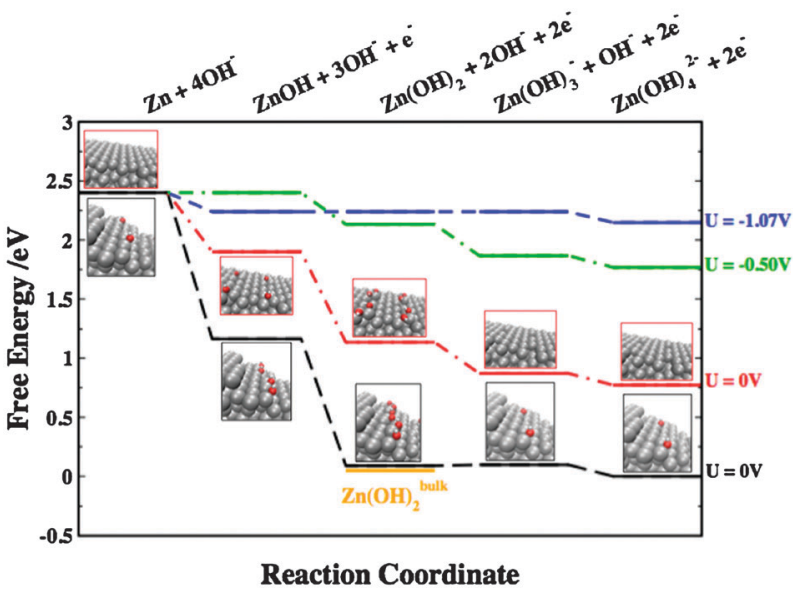

Fig. 4 Free energy diagram for $\mathrm{Zn}$ dissolution at $\mathrm{pH}$ 14. Black and red lines are the free energy levels at $U=0 \mathrm{~V}$ for the kink and $\mathrm{Zn}(0001)$ surface, respectively. Blue and green lines are the free energy levels at the minimum overpotential where all the steps are downhill in free energy, for the kink and $\mathrm{Zn}(0001)$ surface, respectively. In the kink model, both $\left[\mathrm{Zn}(\mathrm{OH})_{3}\right]^{-}$and $\left[\mathrm{Zn}(\mathrm{OH})_{4}\right]^{2-}$ levels are fixed relative to $\mathrm{Zn}$ by the experimentally determined dissolution potentials. The last two steps of the red and the green lines are the free energies of vacancy formation which are added on top of the experimental $\left[\mathrm{Zn}(\mathrm{OH})_{3}\right]^{-}$and $\left[\mathrm{Zn}(\mathrm{OH})_{4}\right]^{2-}$ levels on the $\mathrm{Zn}(0001)$ surface. The $\mathrm{Zn}(\mathrm{OH})_{2}$ bulk formation energy is indicated in orange for comparison. Corresponding designated structures are represented in the figure for both the kink and the $\mathrm{Zn}(0001)$ bare surfaces with black and red borders, respectively.

agreement between the bulk $\mathrm{Zn}(\mathrm{OH})_{2}$ formation energy and the two $\mathrm{OH}$ species adsorbed on a kink atom, which once more justifies the kink model.

This study is based on a purely thermodynamic analysis, however as kinetics does not play a major role, ${ }^{42}$ we believe that this approach is accurate enough to describe the zinc anode dissolution.

\section{Conclusions}

In summary, we have presented a simple analysis of the anode dissolution in the zinc-air battery using both a $\mathrm{Zn}(0001)$ and a kink surface as model systems. We concluded that the kink surface is a much better model for studying bulk dissolution processes. The invariance of the surface morphology before and after dissolution of a kink atom allowed us to calculate potential steps in one dissolution cycle. We have also discussed reasons why it is difficult to make a rechargeable battery. From the calculated $\mathrm{OH}$ adsorption energies and the experimental dissolution potentials we mapped out the FED and showed that there is a small overpotential of $0.13 \mathrm{~V}$ associated with this reaction. This result agrees well with the experimental $0.05-0.1 \mathrm{~V}$ overpotential. The work presented here clearly demonstrates the versatility of DFT in modelling bulk dissolution processes on metal surfaces.

\section{Acknowledgements}

The Catalysis for Sustainable Energy initiative is funded by the Danish Ministry of Science, Technology and Innovation.
This work was supported by the Danish Center for Scientific Computing. Support from the Danish Council for Technology and Innovation's FTP program, the Danish Council for Strategic Research through the Strategic Electrochemistry Research Center and ReLiable, and the US Department of Energy, Basic Energy Sciences is also acknowledged.

\section{References}

1 Duracell Technical/OEM primary systems, http://www1.dur acell.com/OEM/Primary/Zinc/zinc_air_tech.asp.

2 F. R. McLarnon and E. J. Cairns, J. Electrochem. Soc., 1991, 138, 645 .

3 P. Arora and Z. J. Zhang, Chem. Rev., 2004, 104, 4419.

4 K. Harting, U. Kunz and T. Turek, Z. Phys. Chem., 2012, 226, 151.

5 T. Ogasawara, A. Debart, M. Holzapfel, P. Novak and P. G. Bruce, J. Am. Chem. Soc., 2006, 128, 1390.

6 K. M. Abraham and Z. Jiang, J. Electrochem. Soc., 1996, 143, 1 .

7 A. Débart, A. Paterson, J. Bao and P. G. Bruce, Angew. Chem., Int. Ed., 2008, 47, 4521.

8 P. Sapkota and H. Kim, J. Ind. Eng. Chem., 2009, 15, 445.

9 Y.-C. Lu, Z. Xu, H. A. Gasteiger, S. Chen, K. Hamad-Schifferli and Y. Shao-Horn, J. Am. Chem. Soc., 2010, 132, 12170.

10 J. K. Nørskov, J. Rossmeisl, A. Logadottir, L. Lindqvist, J. R. Kitchin, T. Bligaard and H. Jónsson, J. Phys. Chem. B, 2004, 108, 17886.

11 J. Greeley, I. E. L. Stephens, A. S. Bondarenko, T. P. Johansson, H. A. Hansen, T. F. Jaramillo, J. Rossmeisl, I. Chorkendorff and J. K. Nørskov, Nat. Chem., 2009, 1, 552.

12 J. Rossmeisl, Á. Logadóttir and J. K. Nørskov, Chem. Phys., 2005, 319, 178.

13 J. Rossmeisl, Z.-W. Qu, H. Zhu, G.-J. Kroes and J. K. Nørskov, J. Electroanal. Chem., 2007, 607, 83.

14 K. Kinoshita, Electrochemical Oxygen Technology, John Wiley \& Sons Inc., New York, 1992.

15 Y. Gorlin and T. Jaramillo, J. Am. Chem. Soc., 2010, 132, 13612.

16 S. F. Bender, J. W. Cretzmeyer and T. F. Reise, in Handbook of Batteries, ed. D. Linden, McGraw-Hill, Inc., New York, 1995, p. 13.1.

17 V. Neburchilov, H. J. Wang, J. J. Martin and W. Qu, J. Power Sources, 2010, 195, 1271.

18 P. Sapkota and H. Kim, J. Ind. Eng. Chem., 2009, 15, 445.

19 C. W. Lee, S. W. Eom, K. Sathiyanarayanan and M. S. Yun, Electrochim. Acta, 2006, 52, 1588.

20 C. W. Lee, K. Sathiyanarayanan, S. W. Eom and M. S. Yun, J. Power Sources, 2006, 160, 1436.

21 W. M. Haynes and D. R. Lide, CRC Handbook of Chemistry and Physics, 92nd edn, 2012, internet version.

22 J. S. Hummelshøj, J. Blomquist, S. Datta, T. Vegge, J. Rossmeisl, K. S. Thygesen, A. C. Luntz, K. W. Jacobsen and J. K. Nørskov, J. Chem. Phys., 2010, 132, 071101.

23 J. Chen, J. S. Hummelshøj, K. Thygesen, J. S. G. Myrdal, J. K. Nørskov and T. Vegge, Catal. Today, 2011, 165, 2. 
24 J. Greeley and J. K. Nørskov, Electrochim. Acta, 2007, 52, 5829. 25 J. Greeley, Electrochim. Acta, 2010, 55, 5545.

26 P. Strasser, S. Koh and J. Greeley, Phys. Chem. Chem. Phys., 2008, 10, 3670.

27 J. J. Mortensen, L. B. Hansen and K. W. Jacobsen, Phys. Rev. B: Condens. Matter Mater. Phys., 2005, 71, 035109.

28 B. Hammer, L. B. Hansen and J. K. Nørskov, Phys. Rev. B: Condens. Matter Mater. Phys., 1999, 59, 7413.

29 H. J. Monkhorst and J. D. Pack, Phys. Rev. B: Solid State, 1976, 13, 5188.

30 Atomic Simulation Environment (ASE), URL: https/wiki. fysik.dtu.dk/ase, Center for Atomic Scale Materials Design (CAMD), Technical University of Denmark, Lyngby.

31 U. Wedig, M. Jansen, B. Paulus, K. Rosciszewski and P. Sony, Phys. Rev. B: Condens. Matter Mater. Phys., 2007, 75, 215123.

32 CRC Handbook of Chemistry and Physics, ed. D. Lide, CRC Press, New York, 77th edn, 1996.

33 H. Jacobs, A. Niemann and W. Kockelmann, Z. Anorg. Allg. Chem., 2005, 631, 1247.
34 M. Cai and S.-M. Park, J. Electrochem. Soc., 1996, 143, 2125. 35 P. W. Atkins, Physical Chemistry, Oxford University Press, Oxford, U.K., 6th edn, 1998, pp. 485, 925-927, 942.

36 H. Ogasawara, B. Brena, D. Nordlund, M. Nyberg, A. Pelmenschikov, L. G. M. Petterson and A. Nilsson, Phys. Rev. Lett., 2002, 89, 276102.

37 C. Clay, S. Haq and A. Hodgson, Phys. Rev. Lett., 2004, 92, 046102.

38 J. K. Nørskov, J. Rossmeisl, A. Logadottir, L. Lindqvist, J. R. Kitchin, T. Bligaard and H. Jonsson, J. Phys. Chem. B, 2004, 108, 17886.

39 G. S. Karlberg, J. Rossmeisl and J. K. Nørskov, Phys. Chem. Chem. Phys., 2007, 9, 5158.

40 H. A. Hansen, J. Rossmeisl and J. K. Nørskov, Phys. Chem. Chem. Phys., 2008, 10, 3722.

41 Z. Mao and R. E. White, J. Electrochem. Soc., 1992, 139, 1105.

42 J. C. Salas-Morales and J. W. Evans, J. Appl. Electrochem., 1994, 24, 858.

43 V. Tripkovic, E. Skulason, S. Siahrostami, J. K. Nørskov and J. Rossmeisl, Electrochim. Acta, 2010, 55, 7975. 